\begin{tabular}{|c|c|}
\hline \multirow{3}{*}{ 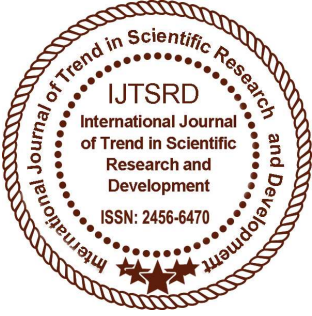 } & $\begin{array}{l}\text { International Journal of Trend in Scientific } \\
\text { Research and Development (IJTSRD) }\end{array}$ \\
\hline & International Open Access Journal \\
\hline & ISSN No: 2456 - 6470 | www.ijtsrd.com | Volume - 2 | Issue - 4 \\
\hline
\end{tabular}

\title{
A Review Paper on Study of Progressive Damage of Composite Structure under Tri Axial Loading by Using Micromechanical based Failure Theories
}

\author{
Mr. Rahul B Gunale \\ Assistant Professor, Mechanical Department, ICOER, JSPM, \\ Wagholi, Pune, Maharashtra, India
}

\begin{abstract}
Paper reviewed laminate failure occurred by various means under tri axial loadings by using various micromechanics based failure theories applied under static loading conditions. Experimental data shows that the mechanical behaviour and progressive damage of composite laminates may be different under multi axial loading than under uniaxial loading conditions. The proposed failure model by various authors is an extension of the strain energy failure theory for tri axial loading conditions. The paper summarizes laminate failure which includes initial failure, progressive damage, and final failure for laminate composite designed with different ply and material configurations. The paper also reviewed the structure failure due to stress concentration effects arrive due to edging effects. The aim of paper is to present failure of complex composite geometries/laminate under complex loading conditions.
\end{abstract}

Keywords: Composite laminate, failure, Strain energy model, progressive damage etc

\section{INTRODUCTION}

Composite material is combination of two phases designed for better engineering properties. Composite materials used in design of structures such as mud and straw, now days they are continue to be used in concrete. Fiber is stiff member which is embedded in matrix and exhibits more load sustaining capacity. Load on structure received by matrix and transferred to fiber. Fibers are oriented in different directions to enable to achieve desired property configuration and strength. Fiber can be woven braided or separately placed apart. Fiber may be continuous or discontinuous and decision will be taken based on sort of property configuration needed. Matrix may consist of polymer, ceramics or metal. Fiber and matrix forms the lamina structure which would have definite width, length and thickness, when several such laminas placed one above the other (The lamina fiber either may have same or different orientation) the resultant structure would be called as laminate. The property configuration of lamina and laminate is different from each other, and despite made of same material the ultimate load sustaining capacity and loading behavior is not same. The failure initiates from lamina and reach to laminate which leads ultimate structure failure.

The broad application of fiber-reinforced composite laminates has led to a large amount of research into their progressive damage and failure, and many authors have devoted their work in similar context. There are numerous progressive and failure models that predict mechanical response of structure which includes all loading configurations, boundary conditions, lay-ups, and thicknesses of composite laminates. Categorizing the existing failure theories is expected to highlight with regards to composite laminate progressive damage and failure where existing literature may be sparse. Existing failure criteria are classified as micromechanics or macro mechanics based, the structure failure analysed at lamina constituent level is recognized micromechanical approach where failure analysis at 
International Journal of Trend in Scientific Research and Development (IJTSRD) ISSN: 2456-6470

lamina level recognised as macro mechanical lamina behaviour before occurrence of ultimate approach.

failure, and thus knowledge of such few responsible parameters would enables the technical fellow to

The failure analysis of composite structure is an important aspect to understand to enhance its utility and scope both. While trying in similar context the failure theories (Micromechanical based) are discussed throughout paper which project light on nature of loading, factors responsible in failure, and design robust structure to serve said application in desired manner.

\section{Authors and failure investigation work based on Micromechanical failure theories:}

\begin{tabular}{|c|c|c|}
\hline \multicolumn{3}{|r|}{ Micromechanics Model } \\
\hline $\begin{array}{l}\text { Sr. } \\
\text { No. }\end{array}$ & Author \& Year & Research conclusion \\
\hline 1 & $\begin{array}{l}\text { Chamis } \quad \& \\
\text { Sendeckys (1968) }\end{array}$ & Ply is macroscopically homogeneous, elastic and orthotropic \\
\hline 2 & Bolotin (1965) & Strength of fiber greater than matrix \\
\hline 3 & Bolotin (1966) & Macroscopic homogeneity of composite and not valid under few circumstances \\
\hline 4 & Mccartney (2002) & $\begin{array}{l}\text { Final lamina failure is accumulation of many cracks. The failure parameters can be } \\
\text { considered mainly are, stress at crack tip, bridging effect of fiber and crack } \\
\text { interaction etc. } \\
\text { Compressive strength of fiber is greater than tensile strength. }\end{array}$ \\
\hline 5 & Aboudi (1989) & Behavior of composite is function of cell repetition \\
\hline 6 & Mallick (2008) & $\begin{array}{l}\text { Crack initiation, propagation when stress intensity reaches to its peak value, } \\
\text { further prorogation in crack leads structure failure, but there is no fixed pattern of } \\
\text { crack propagation as every investigation had ever surface out different one. }\end{array}$ \\
\hline 7 & $\begin{array}{l}\text { Harris \& Morris } \\
(1985)\end{array}$ & $\begin{array}{l}\text { Calculated stress intensity factor by graphical method which promotes crack } \\
\text { propagation. Strain energy release also adopted fracture growth resistance }\end{array}$ \\
\hline 8 & Bai (2011) & $\begin{array}{l}\text { Mechanism determines fracture mode is not suited for all types of failure. } \\
\text { Micromechanics model used fracture mechanics principle to model failure of } \\
\text { material structure }\end{array}$ \\
\hline 9 & Aveston (1971) & Fiber holds in matrix by means shear force. \\
\hline 10 & $\begin{array}{l}\text { Marshall \& Cox } \\
(1985)\end{array}$ & $\begin{array}{l}\text { Predicts fracture toughness. Use stress intensity approach to predict matrix failure } \\
\text { by means cracking }\end{array}$ \\
\hline 11 & Budianky (1986) & Studied the propagation of matrix crack. \\
\hline 12 & $\begin{array}{l}\text { Hutchinson } \& \\
\text { Jensen }(1990)\end{array}$ & $\begin{array}{l}\text { Studied fiber debonding and energy release, the stress magnitude responsible in } \\
\text { generation of debonding crack }\end{array}$ \\
\hline 13 & $\begin{array}{lll}\text { Nairan } & \mathrm{H} & \mathrm{V} \\
(1992) & & \end{array}$ & Studied variation analysis of stresses and thus formation of outer ply crack \\
\hline 14 & Mecartney (1998) & $\begin{array}{l}\text { Cracking of transverse plies under the uni-axial and bi-axial loadings applied } \\
\text { independently }\end{array}$ \\
\hline 15 & Budiansty (1995) & $\begin{array}{l}\text { Tensile strength of composite with first crack, author also studied tensile strength } \\
\text { of ceramics composite. }\end{array}$ \\
\hline 16 & Crack Zok (1997) & Line spring representation of crack as a result of fiber bridging \\
\hline 17 & Pagano (1998) & Presented debonding modes of failure in matrix \\
\hline 18 & $\begin{array}{l}\text { Gonazelez-Chi } \\
\text { \&Young (1998) }\end{array}$ & $\begin{array}{l}\text { Investigates failure of Polyethylene fiber, inline to the same study author has also } \\
\text { studied axial stress distribution, shear stress at de bonded transition, debonding } \\
\text { process in terms of interfacial fracture energy criterion etc. }\end{array}$ \\
\hline 19 & $\operatorname{Cox}(1952)$ & $\begin{array}{l}\text { Developed shear log model which depicts failure load redistribution on lamina, } \\
\text { where fiber carries tensile load and matrix as shear, the stiffness of fiber would be } \\
\text { more than matrix stiffness. }\end{array}$ \\
\hline 20 & Peter Amaya & $\begin{array}{l}\text { Stress filed using CLT \& FEA combined with strain energy based criteria } \\
\text { investigates progressive failure of laminate under uniaxial and multi-axial } \\
\text { loadings. }\end{array}$ \\
\hline
\end{tabular}


International Journal of Trend in Scientific Research and Development (IJTSRD) ISSN: 2456-6470

\begin{tabular}{|c|c|c|}
\hline 21 & Mallick (2008) & Fiber occupied larger volume and takes major part of loadings. \\
\hline 22 & Mallick (2008) & $\begin{array}{l}\text { Proved that, carbon fiber have varying tensile modulus under different loading } \\
\text { conditions }\end{array}$ \\
\hline 23 & Mallick (2008) & Low viscosity of epoxies allowed to proceed them for matrix manufacturing \\
\hline 24 & Mallick (2008) & $\begin{array}{l}\text { Void formed tends to invent micro crack which tends to propagates with respect to } \\
\text { increase in load magnitude. }\end{array}$ \\
\hline 25 & Gordon (1964) & $\begin{array}{l}\text { Magnitude of In Plane Shear stress and Transverse shear stress reach maximum at } \\
\text { crack tip which tends to propagate the crack. }\end{array}$ \\
\hline 26 & Pagano (1970) & $\begin{array}{l}\text { Magnitude of inter laminar shear depends on fiber orientation, for } 0 \text { and } 90 \\
\text { degrees fiber it is noted null and highest for fiber oriented }+35 \text { or }-35 \text { degrees }\end{array}$ \\
\hline 27 & Waddoups (1969) & $\begin{array}{l}\text { Lamina shows nonlinear behaviour for shear loading, and laminate has nonlinear } \\
\text { stress-strain curve as a result of this lamina degradation is limited to that } \\
\text { respective lamina and let not transferred to adjacent lamina. }\end{array}$ \\
\hline 28 & Chiu (1969) & Analyze orthotropic material failure in one direction \\
\hline 29 & Hill (1950) & $\begin{array}{l}\text { Mode of failure determined from individual layer strain, the maximum value of } \\
\text { strain induced was limited to ultimate strain of laminate }\end{array}$ \\
\hline 30 & Foge (1973) & $\begin{array}{l}\text { Investigates behaviour of lamina and came to predict nonlinear relationship } \\
\text { between transverse normal stress and shear stress }\end{array}$ \\
\hline 31 & Sandhu (1974) & $\begin{array}{l}\text { Degraded lamina due to transverse and shear load still can sustain longitudinal } \\
\text { load, the stress-strain behavior is found non linear }\end{array}$ \\
\hline 32 & Brown (1976) & $\begin{array}{l}\text { Lamina failed in longitudinal direction can sustain load in transverse direction and } \\
\text { vice versa }\end{array}$ \\
\hline 33 & $\begin{array}{l}\text { Yeow \& Brinjon } \\
(1977)\end{array}$ & $\begin{array}{l}\text { Symmetric laminates with off axis fiber orientation, subjected to uni-axial } \\
\text { loadings. Laminate configuration }[0 / 30 /-30 / 0] \text {, the failure occurred to } 30 \text { and }-30 \\
\text { degree laminas }\end{array}$ \\
\hline 34 & $\begin{array}{l}\text { Pack-Forster } \\
(1970)\end{array}$ & $\begin{array}{l}\text { Transverse and shear failure associated with matrix failure, the theory also used to } \\
\text { predict start of yielding earch and }\end{array}$ \\
\hline \multirow[t]{2}{*}{35} & Nahas (1986) & $\begin{array}{l}\text { Amount of load carried by failed lamina modeled by exponential degradation } \\
\text { method. The rate of modulus degradation after first ply failure/post initial failure } \\
\text { will be exponential and instantaneous }\end{array}$ \\
\hline & \multicolumn{2}{|r|}{ Load distribution Model } \\
\hline 36 & Nairn (1988) & Stiffness of fiber is more than matrix, fiber caries tensile load and matrix as shear. \\
\hline 37 & $\begin{array}{l}\text { Mishnaevsky \& } \\
\text { Brondsted } \\
(2009)\end{array}$ & Analyze fiber failure and load distribution among remaining intact fiber's \\
\hline 38 & $\begin{array}{l}\text { Mishnaevsky \& } \\
\text { Brondsted } \\
(2009)\end{array}$ & $\begin{array}{l}\text { Author has modeled interaction between multiple fiber breaks, state of stress around } \\
\text { single fiber break and used to model stress distribution in composite with multiple } \\
\text { fiber break. }\end{array}$ \\
\hline \multirow[t]{2}{*}{39} & Daniel (1945) & $\begin{array}{l}\text { Bundle of similar fiber with same elastic properties subjected to tensile load } \\
\text { accounts the progressive damage of each other Progressive damage in brittle fiber } \\
\text { leads ductile behavior of composite }\end{array}$ \\
\hline & \multicolumn{2}{|r|}{ Micro buckling model } \\
\hline 40 & $\begin{array}{l}\text { Kyriakides } \\
(1995)\end{array}$ & $\begin{array}{l}\text { Predicted reduced shear modules to avoid overestimation of strength by using } \\
\text { theory of plasticity }\end{array}$ \\
\hline 41 & Argon (1972) & $\begin{array}{l}\text { Fiber reinforced has region of misalignment causes shear stress concentration and } \\
\text { reduces value of shear modulus. }\end{array}$ \\
\hline 42 & Argon (1972) & Buckling stress is inversely proportional to fiber misalignment angle \\
\hline
\end{tabular}


International Journal of Trend in Scientific Research and Development (IJTSRD) ISSN: 2456-6470

\begin{tabular}{|c|c|c|}
\hline 43 & $\begin{array}{l}\text { Weaver } \& \\
\text { Williams }(1975)\end{array}$ & $\begin{array}{l}\text { Composite with low fiber volume subjected to compression and hydrostatic loading } \\
\text { leads kinking/kink band }\end{array}$ \\
\hline 44 & $\begin{array}{l}\text { Budiansky } \\
(1983)\end{array}$ & $\begin{array}{l}\text { Kink band formation is function of axial stress, shear strain and fiber misalignment } \\
\text { angle with principal axis }\end{array}$ \\
\hline 45 & Pimenta (2009) & $\begin{array}{l}\text { Kink band formation is function of fiber misalignment angle which laterally } \\
\text { supported by elasto-plastic matrix }\end{array}$ \\
\hline 46 & $\begin{array}{l}\text { Yerramallis \& } \\
\text { was (2003) }\end{array}$ & Compression and shear loading initiate composite failure in terms of spitting \\
\hline 47 & Aboudi (1989) & $\begin{array}{l}\text { Effective moduli's, fatigue strength and coefficient of thermal expansion are the } \\
\text { functions of interaction between adjacent cells. Each such cell has sub cell which is } \\
\text { occupied by fiber and matrix. The cell methods also used to predict macroscopic } \\
\text { failure and local phenomenon such as fiber rotation, crack initiation etc. }\end{array}$ \\
\hline 48 & Hage (2009) & $\begin{array}{l}\text { Combines cell method and FEA to predict three dimensional engineering elastic } \\
\text { properties. }\end{array}$ \\
\hline 49 & $\mathrm{Ha}(2010)$ & Modeled unit cell of microstructure to derive ply properties from constituents. \\
\hline 50 & $\begin{array}{l}\text { Bednarcyk } \\
(2010)\end{array}$ & $\begin{array}{l}\text { Material nonlinearity is function of material damage. Author also investigates } \\
\text { progressive damage of lamina }\end{array}$ \\
\hline \multicolumn{3}{|r|}{ Rule of mixture and multi continuum approach } \\
\hline 51 & $\begin{array}{l}\text { Suresh } \\
\text { Mortenson } \\
(1998)\end{array}$ & Reviewed rule of mixture and possible progressive failure of composite \\
\hline 52 & $\begin{array}{l}\text { Ashkenazi } \\
(1965)\end{array}$ & $\begin{array}{l}\text { Author proved normal strength is twice the shear. Further investigations determined } \\
\text { interaction coefficient between fiber and matrix for } 45 \text { degree fiber }\end{array}$ \\
\hline 53 & $\begin{array}{l}\text { Hashim } \& \\
\text { Rotem (1973) }\end{array}$ & Proposed several equation describing fiber and matrix failure \\
\hline 54 & Hashin (1980) & Distinguished tensile and compressive failure for fiber and matrix \\
\hline
\end{tabular}

\section{Conclusion}

$>$ Prediction of mechanical response of laminates under different loading condition can be done by using progressive damage and failure model suggested by various authors who are dealing over the years in context behavior and failure analysis of lamina and laminate composite under complex sets of loading.

$>$ Use of classical lamination theory is recommended to model uniform stress filed which otherwise impossible to invent.

$>$ Predicted behavior of undamaged lamina by means of CLT (Classical Lamination Theory) agreed with experimental results.

$>$ Initial, intermediate, and final failures of the unidirectional and multidirectional laminate tubular specimens can be predicted adequately by the strain energy theory combined with CLT.

$>$ Stress concentration occurs at free edge leading to exhibit highest stress at respective location.

$>$ Matrix failure at the 0 degree plies occurred at center.

Load transfer from damaged lamina to undamaged lamina depends on ply layup.

In plane and out of plane shear do not increases in 0 degree ply after occurrence of initial failure.

\section{References}

1. Peter Amaya, 2012, 'Progressive damage and failure model for composite laminates under multi axial loading conditions', MS Thesis, Ohio State University.

2. Madhujit Mukhopadhaya, 2005, 'Mechanics of Composite Material \& Structure', Text book, ISBN 9788173714771

3. Valery V Vasiliev \& Evgeny V Morozov, 2001, ' Mechanics \& Analysis of Composite Materials', text book, ISBN 0-08-042702-2. 